\title{
LAND-USE RIGHTS FOR AGRICULTURAL LAND IN UKRAINE
}

DERECHOS SOBRE EL USO DE LA TIERRA PARA LA TIERRA AGRÍCOLA EN UCRANIA

\author{
Dmytro Fedchyshyn* \\ Iryna Ignatenko" \\ Liudmyla Leiba ${ }^{* * *}$
}

\begin{abstract}
The article deals with the rights to agricultural land under the conditions of the moratorium on the alienation of agricultural land in Ukraine. Currently land lease is the most widespread land-use right in Ukraine. The purpose of the article is to investigate the features and prospects of the functioning of the land market in Ukraine and to increase investor interest in it. The dialectical method made it possible to consider the development of land-use rights in Ukraine, to formulate proposals for improving existing legislation. The method of comparative legal analysis made it possible to compare the system of relations of land ownership and lease in Ukraine and other countries of the world. Much attention has been paid to the abolition of the moratorium on the purchase of agricultural land in Ukraine, which will lead to a gradual increase in the share of entrepreneurial activity on owned land with an optimal ratio of land lease. Based on the features of agricultural land lease, the following positive points are highlighted: 1) the availability of long-term lease guarantees the tenant's stability in land use and promotes better planning and investment attractiveness; 2) the ability to set a fixed size of land rent without taking
\end{abstract}

\footnotetext{
"Ph.D., Senior Lecturer of the Department of Civil Law of Zaporizhzhia National University (Zaporizhzhia, Ukraine). marlynkh@gmail.com

** Ph.D., Associate Professor of the Department of Land and Agrarian Law of Yaroslav Mudryi National Law University (Kharkiv, Ukraine). irena.nekosargot@gmail.com

*** Ph.D., Associate Professor of the Department of Land and Agrarian Law of Yaroslav Mudryi National Law University (Kharkiv, Ukraine). luda_nuau@i.ua
} 
into account the normative monetary valuation; 3 ) rents for agricultural land in Ukraine continue to be much lower than in other countries.

Keywords: Land Lease, Land Law, Land Use, Agricultural Production, Land Plot

Resumen: El artículo trata sobre los derechos a las tierras agrícolas en las actuales condiciones de la moratoria sobre la enajenación de tierras agrícolas en Ucrania. Hoy el arrendamiento de tierras es el derecho de uso de la tierra más extendido en Ucrania. Aqui se investigan las características y perspectivas del funcionamiento del mercado de tierras en Ucrania, y cómo esto aumenta el interés de los inversores en él. El método dialéctico permitió considerar el desarrollo de los derechos de uso de la tierra en Ucrania, para formular propuestas de mejora la legislación existente. El método de análisis jurídico comparativo permitió comparar el sistema de relaciones de propiedad y arrendamiento de tierras ucraniano con el de otros países del mundo. La atención se ha centrado en la abolición de la moratoria sobre la compra de tierras agrícolas en Ucrania, lo que puede aumentar gradualmente la participación empresarial en adquisición de tierras con una proporción óptima de arrendamiento de tierras. En las nuevas características del arrendamiento, se destacan los siguientes puntos positivos: (i) la disponibilidad de arrendamientos a largo plazo garantiza la estabilidad del arrendatario en el uso del suelo y promueve una mejor planificación y atracción de inversiones; (ii) la capacidad de establecer un tamaño fijo de renta de la tierra sin tener en cuenta la valoración monetaria legal; y, (iii) los alquileres de tierras agrícolas en Ucrania siguen siendo mucho más bajos que en otros países.

Palabras clave: Arrendamiento de tierras, ley de tierras, uso de la tierra, producción agrícola, predios

Sumario. I. Introduction. II. Materials and methods. III. Ukrainian land market and its moratorium on land sales. IV. Land lease. V. Conclusions. References.

\section{INTRODUCTION}

Ukraine has an extremely rich land-resource potential. According to experts, up to $25 \%$ of the world's black soil areas are located on the territory of Ukraine. The country has 27.8 million hectares of black soils $(60 \%$ of the total land area), and the area of agricultural land with such soils is 25.3 
million hectares (Tupalska, 2017). In this context, it should be noted that if Ukraine in Europe occupies $5.7 \%$ of the territory of the continent, then its agricultural lands - almost 19\% (Kulynych, 2011, p. 7).

Ukraine is among the top 10 in the world in production volume of more than 30 types of agricultural products. The agricultural sector is of key importance for Ukraine's economy and attracts increasing policy attention and private-sector investments. Several factors add to the increasing attraction of capital to the agricultural sector, including foreign capital: (i) low cost of labor; (ii) low environmental standards; (iii) the possibilities of obtaining subsidies from the state budget for the development of the agrarian sector; (iv) the possibility of accumulation of large land masses through conclusion of agreements on land (leasing, emphyteusis, joint activity); and, (v) low rent for land.

Currently, the main foreign investors into agriculture in Ukraine are Cyprus, Great Britain, Germany, Poland, France, USA and Netherlands (Figure 1).

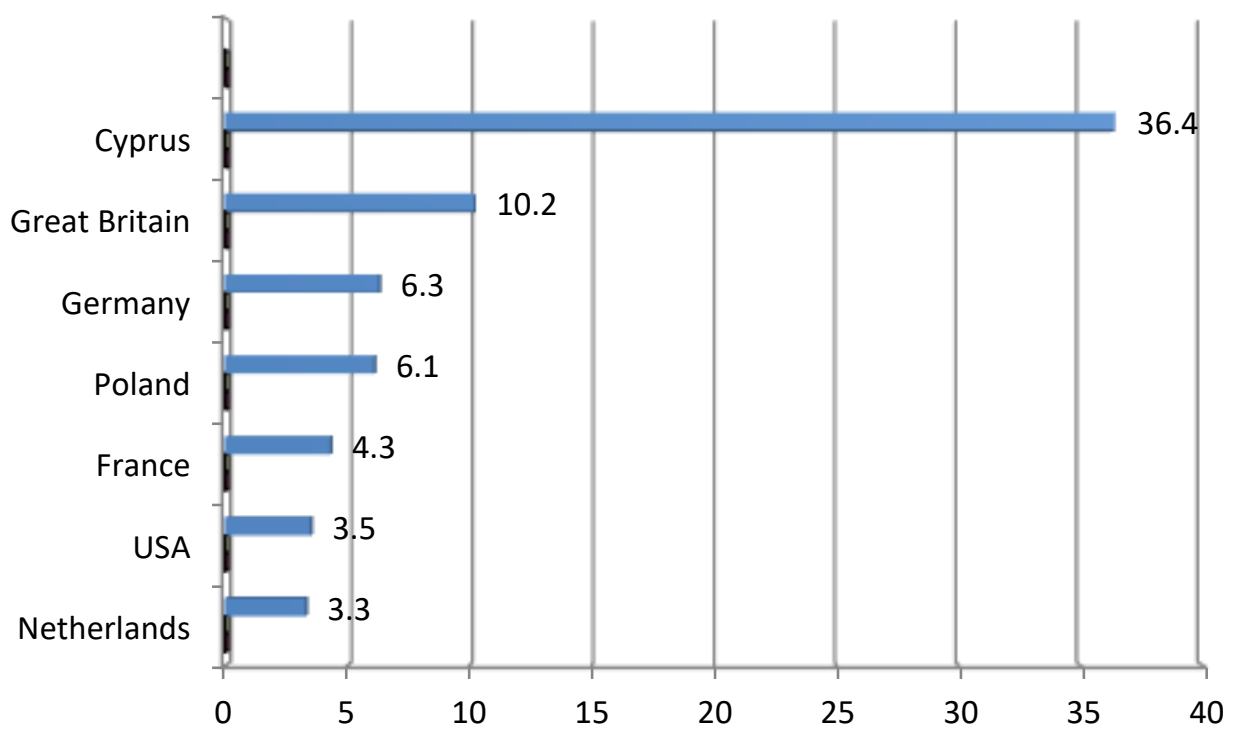

Figure 1. Shares of foreign investors into agriculture in Ukraine (Patyka, 2018, p. 30)

However, despite the interest of investors, the land market in Ukraine is not liberalized today. The main reason for this is the existence of a moratorium on the alienation of agricultural land, which was proclaimed in 2001, and has been prolonged 11 times. Today according to the Land Code of Ukraine (2001), the sale or other means of alienation of agricultural land 
plots and changes in their intended purpose, as well as their inclusion in the authorized capital of enterprises, are prohibited by 2020. However, the absence of the market, and not the contemporary crisis in the economy, is currently the main deterrent for any investor who does not own his land assets. It is argued here that the impossibility to own land plots, combined with the uncertain lease situation, including the risks of non-return of invested funds, deters long-term investments, and therefore compromises the performance of the agricultural sector of Ukraine.

The land reform in Ukraine has begun in 1991. Its strategic purpose was the full transfer of land to those who work on it, protecting the interests of peasants, establishing them as class of rural owners. For this purpose, the privatization of land by brazing and allocating land shares was provided, as well as implementation of different market mechanisms with including of them in the economic turnover: rent, inheritance and emphyteusis etc. Due to the lack of an agricultural land market, sales and mortgage transactions are now inaccessible to economic agents, and donation and inheritance transactions are substantially restricted to prevent shadow deals. Thus, leasing of agricultural lands for over 28 years is in fact the only mechanism for their market circulation, which enables the realization of interests of landowners and land users in the field of land relations on a contractual and competitive basis. In view of this, the problem of development of land lease relations in the agrarian sector of the economy is urgent for scientific and applied research.

\section{MATERIAls AND METHODS}

The methods of the article are determined by the nature, purpose and ways of solving the tasks. The authors use the general scientific and speciallegal methods of scientific knowledge. As the general scientific methods, there are: the dialectical method, which accompanied the entire process of this study and has allowed considering the development of the land relations in Ukraine, formulate points of view for the improvement of the current legislation of Ukraine and propose ways to achieve these goals. The forecast of the impact of the proposed changes or additions to the current legislation of Ukraine, which regulates the investigated social relations, was made using the simulation method. Among the special-legal methods there were used: the method of comparative legal analysis, which has allowed comparing the system of land lease relations in Ukraine and in other countries of the world. According to the formal legal method, the content of norms of law that regulates social relations in this area is disclosed. The use of all these 
methods made it possible to explore the subject of the article in total, taking into account all the interrelations and interdependencies of the topic. Also some generalizations were made as well as theoretical conclusions and practical suggestions were formulated.

The legal and regulatory framework for the study includes the provisions of the Land Code of Ukraine, laws of Ukraine in the sphere of land relations and other normative legal acts, as well as the legislation of foreign states.

\section{UKRAINIAN LAND MARKET AND ITS MORATORIUM ON LAND SALES}

Formation of the market of agricultural land is one of the most controversial and politicized issues of the political life of Ukraine. A "land market" refers to a set of legal and economic relations that arise between the subjects of such a market in the process of market circulation of ownership of land, resulting in a change in their owners or land users. According to Ukrainian legislation, land may be owned or used. The use of land can be permanent (for state and communal property enterprises) or temporary (on a lease). Today, the bulk of agricultural land in Ukraine is processed not by owners, but by users of land plots (tenants). As stated in the literature, the land market's "rental" arm has become the main farmland transaction channel for farmers and landowners in Ukraine (Nivievskyi, Strubenhoff, 2017).

The range of subjects of the right of private ownership of agricultural land is legally restricted. Only citizens of Ukraine and legal entities of Ukraine can act as such subjects. According to of the Land Code of Ukraine (2001): «agricultural land cannot be transferred to the ownership of foreigners, stateless persons, foreign legal entities and foreign states» (Art. 22).

At the same time, according to Article 81 of the Land Code of Ukraine (2001) agricultural land, inherited by foreigners, as well as stateless persons, during the year are subject to alienation. Issues concerning agricultural lands acquired by inheritance by foreign legal entities are resolved in the same way.

As a result, foreigners and stateless persons cannot acquire ownership of land plots for agricultural uses, but there are no restrictions for them on the transfer of these land plots to lease.

The legislation of most developed countries allows the sale of agricultural land. This is due to the fact that the land market is a powerful 
means of stimulating the growth of agricultural production. However, in order for land turnover to contribute to the concentration of land resources in the hands of the most efficient users, many countries, through the development of legislative norms, control land relations, impose restrictions on the acquisition of land into ownership. Among such restrictions, some countries set maximum and minimum sizes of acquired land in order to avoid fragmentation of farmland or the formation of estates, restriction or prohibition of foreigners' rights to purchase farmland. In general, countries such as Germany, France, or Italy, proceed from the principle that land should be provided to a potentially effective land user. In these countries there are rules and institutions that allow agricultural land to be in the hands of those who work it.

For example, the legal model of a moderately restricted agricultural land market (Germany, Italy) is characterized by rather strict requirements for buyers of land. Basically, as the buyers there can be natural persons, including foreigners, and national and/or foreign legal entities, for which the laws of each country have certain requirements. Such requirements are: (i) requirement of residency-living or providing a business activity in the country or location of a land plot in a certain administrative-territorial unit; (ii) experience in agriculture; (iii) obtaining agrarian education; (iv) the obligation not to alienate the land and keep it on its own for several years, etc. This model is characterized by restrictions on the area of land that can be farmed and which a person can acquire for ownership or use, as well as low rates of taxation of land expropriation agreements.

The legal model of a highly restricted agricultural land market (France) is characterized by the dominance of the market of a special authority, which has the right to substitute the buyer's side in any land acquisition transaction, negotiate with the seller a reasonable price for land sale, grant permits for land acquisition transactions. Despite the formal absence of prohibitions on the subject composition or area of land that may be acquired by foreign natural or legal persons, access to the market through such an authority is severely restricted. For example, the broad range of powers of the SAFER (Sociétés d'Aménagement Foncier et d'Etablissement Rural) allows the state to distribute and redistribute land on the market in each region to support its own young farmers and national producers. The preferential taxation of transactions on alienation of land with the participation of SAFER is an important means of regulating the market, because in fact the person primarily wishes to acquire or alienate land plot involving this authority in order not to pay tax.

The legal model of a moderately restricted market with some elements of the free circulation model seems to be the most appropriate for Ukraine 
to implement. According to this approach, access to the land market may be restricted for foreigners and legal entities, but instead be free for Ukrainian citizens, which is inherent in the free market model. In addition, the legal model of moderately restricted circulation of such lands is characterized by: (i) absence of a special authority (regulator); (ii) limiting the maximum area of land that can be acquired by one person; (iii) giving persons preferential rights to acquire land; and, (iv) regressive taxation of income from the alienation of agricultural land.

That's why, one of the debating issues today is the extension of the moratorium on the alienation of agricultural land. The introduction of a moratorium on the alienation of land plots (shares) in Ukraine has been practiced since 2001 with the adoption of the Law of Ukraine "On agreements on the alienation of land parcels (shares)" dated January 18, 2001. At that time, the law prohibited the conclusion of purchase and sale agreements, donation of land share, except for the transfer of their inheritance and in case of redemption of land for state and public needs. The moratorium should have acted to regulate the procedure for exercising the rights of citizens of land parcels (shares) by the Land Code of Ukraine. After the adoption of the Land Code of Ukraine on October 25, 2001, Section X "Transitional Provisions" prohibited the alienation of not only land parcels (shares), but also of land plots for the conduct of peasant (farmer) economy and other commodity agricultural production, i.e. the moratorium was expanded. The Laws of Ukraine from 2001 to 2020 consistently continued the moratorium.

By adopting a number of legislative acts since 2001, the state has deprived the owners of land parcels (shares) and land plots of agricultural land the right to dispose of them. The moratorium is explained differently by the government officials, in particular: it is not the sale of land, but the rules under which land turnover exists, the position of the right to sell land lease is maintained, and it is noted that there are many land turnover models and not all of them provide for land sale (Zugriy, 2016, p. 271).

O. Litoshenko, studying the opinion of the supporters of the moratorium on the sale of agricultural land, submits, referring to their opinion, a number of negative socio-economic phenomena that may arise when it is abolished (Litoshenko, 2014, p. 289). The main problems can be: (i) the acquisition of a large number of arable land by financial-industrial groups, which can lead to the "landing" of peasants and the formation of "latifundia" of Latin American type with employees; (ii) peasants will be able to alienate agricultural land at a price that is substantially lower than economically justified; (iii) large areas of arable land can be concentrated in the property of financial institutions during the mortgage land transition into 
the property of the mortgagor; and, (iv) large tracts of agricultural land will be bought by financial speculators for the purpose of further resale at a higher price, which will lead to an increase in the value of agricultural products and thereby cause inflation.

Despite the fact that the constitutional majority of the Verkhovna Rada of Ukraine (Parliament of Ukraine, the only legislative body that is authorized to adopt laws) is continuing the validity of the moratorium, this issue is discussed lively and keenly by lawyers, economists, politicians, and noted that the existence of a moratorium on alienation of agricultural land has a number of negative consequences. For example, A. Miroshnychenko repeatedly draws attention to the fact that the moratorium is a significant obstacle to the implementation of land reform, the successful exercising of which is not possible without the creation of legal preconditions for land circulation (Miroshnychenko, 2011, p. 317).

Honored Lawyer of Ukraine, Professor G. Balyuk focuses attention on the fact that «(...) almost all agricultural companies are created on the basis of lease relations, more than $80 \%$ of shares are transferred to short-term use, under such conditions. There is the process of alienation of real landowners from of their holdings» (Balyuk, 2006, p. 157).

Therefore, there is no consensus on the lifting of the moratorium today, so political will is required to make the right and prudent decisions to launch the land market. It is clear that it is too difficult to find a format that can satisfy all stakeholders, and this is practically impossible. Since the best agricultural land is divided into shares (approximately 27 million hectares), the total area of private land is about 32 million hectares. Most of the agricultural land belongs to shareholders who are not able to cultivate it, so it must, first of all, go to those who want and can engage in agribusiness. Currently, there are 38.8 thousand farms in Ukraine, $72 \%$ of which have uses land areas up to 100 hectares (for comparison, in smaller European countries their number is measured in hundreds of thousands). From this it is clear that the obstacle is the current moratorium, since its existence will lead to the following negative consequences: (i) the optimization of land ownership and land use, which are formed as a result of sharing of agricultural land, is blocked, leading to the stimulation of negative phenomena of land use through marrows, inclusions, low lands, far lands, etc.; (ii) elderly peasants, their heirs residing in another locality cannot exercise their land ownership; (iii) the creditworthiness of agricultural producers is reduced due to the inability of mortgage lending; and, (iv) the absence of a land market significantly impedes the development of both the agrarian business and the inflow of investments in general, which negatively affects GDP and outflows of investments. It should also be noted that the long-term effect of 
the moratorium has led to significant structural distortions in the agricultural sector. First of all, this is manifested in the formation of super-large agricultural units, «the ten largest of which have about 3 million hectares of land in their land use, receiving a monopoly rent, constantly increasing their land bank» (Martynyuk, 2017, p. 16).

In Ukraine, the legal regulation of the activities of agricultural holding structures is increasingly a subject of debate. Activities along these lines include, for example, the provisions set out in the Commercial Code (2003). In accordance with this law, the agricultural holding company (hereafter, agro-holdings) is considered as a joint-stock company that owns, uses, and disposes of the holding's corporate stakes (shares) of two or more corporate enterprises. In other words, these are production structures created by leasing land by powerful industrial enterprises, financial and service organizations that invest in rural infrastructure development and typically cultivate more than 1,000 ha.

Their composition necessarily includes subjects having agricultural land on the right of ownership or on the right of lease, which in turn leads to the monopolization of the land market. As of 2017, the land bank of agroholdings amounted to 5.71 million hectares (Mha), representing $28 \%$ of the land used by agricultural enterprises. At the same time, according to research conducted by the Association Ukrainian Agribusiness Club (2016), the land bank of agro-holding companies will grow by 2020 to 6.25 Mha.

Today Ukraine is approaching the abolition of the moratorium on the sale of agricultural land. As a result, over the past 10 years, large agricultural companies have been actively working to increase their land assets. The total land bank in processing by agricultural holdings from 2012 to 2017 has increased from 5.6 million hectares to 5.95 million hectares. However, these assets have been stable for the past two years. The leaders in the land bank are Kernel (550 thousand hectares), and UkrLandFarming (500 thousand hectares) (Top 10 agricultural holdings of Ukraine, 2018).

Generally, agrarians benefit from a moratorium because the owner who is unable to cultivate his land on his own has to lease it. Such actions for both landowners and the state as a whole, and even more so for the development of the agrarian industry, are more likely to be a big systemic disadvantage than a plus.

Under such conditions, there is no land market, farmers and small landowners have no incentive to invest. As a consequence, a large part of the land is rented by large companies, which have a significant impact on the social structure of the village. Today land productivity is far from being in line with Ukraine's potential, so a long-term investment is needed to improve it. Foreign investors, companies with the necessary knowledge and 
equipment, hesitate to invest in Ukraine because of the lack of legal guarantees. A favorable legal climate is needed to improve the agricultural sector. So it is important to remember that the land issue is mostly political. The experience of foreign countries offering a number of alternative methods is appropriate, in particular, by setting up pre-emptive right of purchase.

In the guidelines to Member States dated October 12, 2017 "On protecting agricultural land from threats such as excessive price speculation and concentration of property rights", the European Commission (2017) stated that establishing by Member States of pre-emptive rights to purchase agricultural land was not in breach of European Union law. This right is available to state, tenant farmers, owners or users of adjacent land and coowners of land.

In most cases, pre-emptive rights to purchase land are granted to the entities listed in the European Commission recommendations: (i) co-owners of the land plot (Lithuania, Slovenia, Poland); (ii) tenants of land (Belgium, Hungary, Romania); (iii) owners of adjacent land plots (Italy, Latvia, Portugal); and, (iv) special institutions (France, Croatia, Latvia).

However, international experience shows that the pre-emptive rights may be given to other categories of persons, such as any farmers or agricultural entities (Slovenia); farmers who farm the land for sale (Lithuania) or the neighboring rural area (Slovakia). The above experience and recommendations of the European Commission may be useful to identify the range of entities with pre-emptive rights to purchase agricultural land in Ukraine.

Establishing pre-emptive rights to purchase land in Ukrainian legislation would facilitate the implementation of a policy of support and development of farms, consolidation of land, and rational distribution and redistribution of agricultural land rights by the state, through authorized bodies. Such authorized bodies may be state bodies implementing the state's land policy, in particular, the StateGeoCadastre.

The land market must be transparent, fair, competitive, efficientthese preconditions are not provided today, and there is no proper legal field. The greatest risks may be posed in the Law about land circulation itself. As for today, it is unclear whether there will be restrictions on the maximum amount of land resources that can be concentrated in one hand; whether foreigners will be allowed to buy land; who will check the transparency of the land purchase agreements and so on.

The European Court of Human Rights has also considered the problems of the land moratorium and the restriction of ownership of land of 
a large number of Ukrainian citizens in its judgment in Zelenchuk and Tsytsyura v. Ukraine (European Court of Human Rights, May 22, 2018).

In particular, the European Court of Human Rights came to the conclusions that should be taken into account when implementing this judgment and preparing for the introduction of circulation of agricultural land in Ukraine: (i) it is necessary to ensure a balance between the general interests of the state and society and the property rights of owners of agricultural land, which, in addition to the complete abolition of the prohibition of alienation of agricultural land, can be done by introducing certain means by which a court or public authority will grant an alienation permit; (ii) taking into account the experience of countries of the Council of Europe that have introduced market of agricultural land and provided various restrictions on it, opening up the agricultural land market in Ukraine should not deprive Ukraine of effective mechanisms for the protection of land resources, and therefore different restrictions and remedies may be imposed; (iii) European Court of Human Rights has not obliged Ukraine to adopt a law on the circulation of agricultural land within a specified period; and, (iv) if the state does not resolve the problem of the moratorium on the alienation of agricultural land, then European Court of Human Rights may award monetary compensation to each land owner who will turn to it for protection of property rights.

European Court of Human Rights has also noted that it does not require the creation of a market for agricultural land without restrictions, and that the state remains free to choose what measures to take. This guideline is formulated in paragraph 150 of the Judgment and it is evident from this that legislative changes as such are not binding. Therefore, the implementation of the decision can be taken by the courts. The only requirement is that these changes must be systemic in nature: it cannot be limited, for example, to allow only Mrs. Zelenchuk or only Mr. Tsytsyura to sell their land or pay them compensation from state funds.

Observance of the principle of legal certainty in order to preserve the stability of legal regulation and the predictability of legislative policy must be taken into account by the legislator both when adopting new laws and amending existing legislation. This also applies to the principles of legal regulation in the field of land relations, which should ensure that all features of the land as an object of property of the Ukrainian people and social relations that arise in connection with the citizens' realization of the land ownership are taken into account.

However, contrary to the above, the contested norms of clauses 14, 15 of section X "Transitional provisions" of the Land Code of Ukraine (2001), which extended the moratorium on the sale or otherwise alienation of 
agricultural land, do not way predictability of legal relations concerning the realization by citizens of the powers to dispose of agricultural land owned by private property, which violates the principle of the rule of law enshrined in Article 8 of the Constitution of Ukraine (1996).

Articles 13 and 14 of the Constitution establish the equality of subjects of property right before the law and the state guarantee of land ownership. According to the Article 41: «everyone has the right to own, use and dispose of his property. Private property is inviolable».

Therefore, when there is a principle of equality of land ownership of different entities stated in Article 5 of the Land Code of Ukraine (2001), it is difficult to explain why landowners of agricultural land subject to the moratorium cannot generally dispose of them in a manner prescribed by law for landowners of other categories of land.

In addition, the basis for the introduction of bans on the alienation of agricultural land is a formal (before the entry into force of the law on the circulation of agricultural land), and not a substantive criterion, which is required to determine whether such prohibitions comply with the rule of law.

Although the interference with the exercise of property rights is envisaged by a legislative act (clauses 14, 15 of Section X of the Land Code), such interference cannot be considered admissible and proportionate, since the absence of time limits of the said provisions undermines the idea of legal certainty (predictability) and the rule of law. Such interference by the state in the realization of the property rights of natural persons and legal entities on land is also disproportionate, since, despite the fact that land owners bear real economic losses (non-market rent, impossibility to dispose of their property), these restrictions are not accompanied by any compensations from the state.

The limits of interference of the legislature in the sphere of private property rights and freedom of business activity in the form of restrictions and prohibitions must meet the criterion of proportionality as an element of the rule of law. In assessing proportionality, it should be determined whether it is possible to achieve the legitimate aim pursued by measures that would be less burdensome for human rights and freedoms. Restrictions should not be excessive or greater than necessary to achieve the intended purpose.

The final point in this case should be set by the Supreme Court.

\section{LAND LEASE}

Improving the lease of agricultural land is a strategic imperative for developing land relations in Ukraine. This is especially important for the 
harmonization of interests of landowners and tenants, when the first ones are interested in maximizing the income from the land plot, land share, and the second - in minimizing costs, maximizing profits per unit area, forming a coherent lease of land in the long run and minimize the risks of opportunistic behavior by landowners.

At the same time, land lease relations are a decisive factor in influencing the production activity of agricultural enterprises and farms, which contributes to their successful development, rationalization of size in conditions of lack of financial resources and/or the market of agricultural land, and leads to an increase in economic efficiency of land use. In addition, the rental market helps to create an attractive investment climate for domestic and foreign investors in Ukraine, without violating the national security and sovereignty of the country.

Land lease relations have become widespread in the conditions of corporatization of business, as a sales market for land resources have not yet materialized. Agricultural land lease is also widespread in western countries. For example, in the United States the share of leased land reaches $70 \%$. In Central and Eastern Europe, on average $40 \%$ of farmers lease land for agricultural production (Dankevych, 2007, p. 139). Share of leased land in countries of the world are shown below (Figure 2).

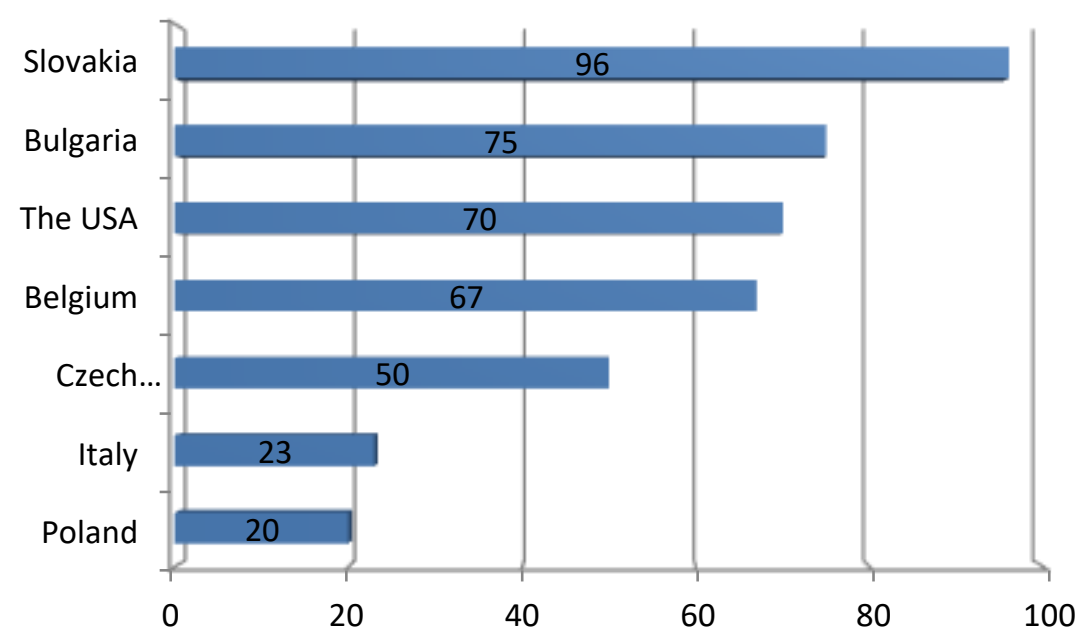

Figure 2. Share of leased land in countries of the world (Miroshnychenko, 2012)

As of 2017, in Ukraine 27,627 land lease agreements for commercial agricultural production on slight over 1 Mha were concluded. The largest tenants are agricultural enterprises who lease 16 million hectares, farms 
households 3 Mha, and other tenants 2 Mha. The average duration of the land leases is 7.6 years (Nizalov, 2018).

Foreigners and stateless persons can also lease agricultural land, as guaranteed by the Law of Ukraine "On Land Lease".

The land lease agreement is concluded between the landowner, on the one hand, and the tenant. Lease conditions vary from country to country, but typically are of two main types. The first is characterized by regulation by the state of the minimum size of the rent and the terms of agreements. As a rule, these agreements are long-term and tend to be more profitable for tenants. For example, in France, agreements on lease of agricultural land are concluded for at least 9 years. Leases for 18 (long-term) and 25 (professional, career) years are also extended. SAFER has been given broad powers to intervene in agreements between market participants, negotiate prices with them, use pre-emptive right to acquire land and grant licenses for contracts worth more than 38 million euro. This allows the state, with the help of SAFER, to distribute and redistribute land on the market in each region to support its own newly established farms.

The second type is based on the achievement of a bilateral agreement between the landowner and the tenant. The terms of the agreement and the size of the rent are determined solely by market conditions. Examples for this type include Germany, Sweden, and the Czech Republic. In Italy and the United Kingdom, both types of lease agreements are in place (Fedchyshyn, Ignatenko \& Shvydka, 2019, p. 108).

In Ukraine, the involved parties are obliged to agree on three conditions for a lease agreement: the object of lease (cadastral number, location and size of land plot); term of the lease agreement; a rent with an indication of its size, indexation, method and conditions of calculations, the order of its introduction and review, liability for non-payment.

The legislation establishes a minimum and maximum duration of the lease agreement in the Land Code of Ukraine (2001) - the maximum term of lease may not exceed 50 years, and the minimum 7 years. Such a legislative restriction is relevant and expedient, both for state and communal lands, and for lands that are privately owned. Establishment of the maximum and minimum terms at the legislative level is one of the mechanisms for ensuring sustainable land use, preventing degradation processes of soil cover, and increasing soil fertility. It also should be emphasized that the specific term of the land lease agreement is determined by the parties within such legislative limits. The practice of establishing minimum lease terms is also widespread in developed countries. For example, in the Netherlands, the minimum term of leasing a land plot is 6 years, and in cases of using such land plots for the farming 12 years. In Switzerland, the minimum lease 
term is 9 years, and the use of land is strictly regulated by legislation on environmental norms and protection of animals (Cabinet of Ministers of Ukraine, 2017).

We can conclude that the advantages of long-term lease are the stability of land tenants' use, which facilitates better planning and investment, the possibility of applying multi-unit crop rotation. The optimum for the land is the duration of the lease at the time of crop rotation, that is, four to ten years. Such terms enable tenants to use land more efficiently to receive a long-term return on their invested capital. Taking into account that in Ukraine traditional crop rotations with the period of rotation of fields for six, eight and ten years are the most widespread, the establishment by the current legislation of the term of lease for not less than seven years, is a logical, but too simplistic, way of solving the issue. Since the quality of a land plot is one of the priority interests of the landowner, it is in his interests to develop a system of crop rotation of his land plot. Therefore, in the case of the transfer of land for agricultural use for commercial agricultural production or for a peasant farm, the agreement should include landowner's duty to develop a system of crop rotation of land and to link the term of the lease agreement with the onset of the corresponding conditions (the period of rotation of the main crop rotation).

Today the amount of the rent for the use of agricultural lands of state or communal property cannot exceed $12 \%$ of the normative monetary valuation in Ukraine. In this regard, the use of state and communal agricultural lands based on lease has become significantly more costly for tenants.

Speaking of the rent for the use of agricultural lands that are privately owned, it is recommended (but not necessary) to set the rent to at least 3\% of the normative monetary valuation of the land plot. The current legislation of Ukraine permits the establishment of a fixed amount of rent for the land of private property, without calculating it from the normative-monetary valuation. Knowledge of this aspect will save time and money needed to obtain a normative monetary valuation of land plots and will simplify the administration of lease payments.

As practice shows, in different regions of Ukraine, not all tenants adhere to the norms regarding the size of rent for land use, which is recommended to be not lower than $3 \%$ of the normative monetary valuation of land plots. The lowest rent (1.4\% of the normative monetary valuation) is paid in the Zakarpattia region, and the largest (3.9\%) is in the Poltava region. At the same time, in Cherkassy, Kharkiv, Rivne, and Zhytomyr regions all land lease agreements are concluded with a rate of not less than $3 \%$ of the normative monetary valuation. Taking into account the market situation and 
agrarian practice in Ukraine, national experts consider as optimal the size of land lease at the level of $8 \%$ of the normative monetary valuation (StateGeoCadastr, 2016).

In 2017 in Ukraine, the highest rents for using agricultural land were found in Cherkassy and Poltava regions with 110 and 90 USD/ha respectively, while in other areas it ranged from 35 to $60 \mathrm{USD} / \mathrm{ha}$. The average rent across Ukraine is 50 USD/ha (StateGeoCadastr, 2017).

The rental rates for agricultural land in Ukraine are six to eight times lower than in the countries of European Union, which are due to the considerably higher incomes of agribusiness in European Union, also supported by subsidies from the European Union Common Agricultural Policy.

In our opinion, lease agreements for agricultural land should be based on the principle the longer the lease of land, the higher the level of rent. It is also advisable to include gradually increasing rental payments in the lease contract of agricultural land, which will declare the serious intentions of the tenants to conduct agricultural production on the leased land. For a guaranteed business, the tenant must be sure of the long-term lease rights, otherwise he or she may not have sufficient incentives to maintain the fertility of the land and to pursue land use with a long-term. At the same time, landowners, especially those ones who own small land plots, will be sure in the benefits of transferring their property to a long-term lease.

Therefore, optimal land use can be achieved both through the purchase of land and its lease. But if you compare these land uses in terms of many processes that have a positive effect on the efficiency of the agricultural business as a whole, efficient and rational use of land in particular, it can be noted that land ownership for entrepreneurs is more profitable than lease because it promotes capital raising, improves the conditions for management and investment, and is a guarantee against the possible termination of leases to change the purpose of the land.

The owner of the land, who independently performs economic activity on it, is naturally interested in using it effectively and getting the most out of it. At the same time, maintaining soil fertility will be the main condition for effective management for the future. Such a "labor" form of land ownership has advantages over other forms of land ownership, in terms of its rational use, preservation and increase of fertility.

It is important to emphasize that land relations in general and the agricultural land market in particular, in countries with developed market economies are under considerable control and regulatory influence by the state. State regulation of land relations envisages, first and foremost, the creation and functioning of an organized land market and the organization 
of appropriate infrastructure. The main purpose of state regulation of the land market is that agricultural land should be used effectively for its intended purpose, and the landowner should be concerned about preserving its fertility.

Based on the theoretical principles on the agricultural land market in terms of value and its functioning in economically developed countries of the world, it can be argued that, if it is available in Ukraine, farmers will face the problem of choosing: to manage or lease on their own land.

The first form of land use is more advantageous than using it on a lease basis. The lease in this situation can be used as an auxiliary resource, usually limited in time. The existence of a land market should promote the use of land by agricultural enterprises.

In the end, it can be predicted that lifting the moratorium on the purchase of agricultural land in Ukraine will lead to a gradual increase in the share of entrepreneurial activity on own land, with an optimal ratio of land lease. This will help to increase the efficiency of land use, attract investment in agriculture, which will ensure the stability of the development of the agricultural sector as a whole. At the same time, the introduction of the agricultural land market will allow land owners to exercise all their powers, including selling them.

In addition, the International Monetary Fund is in favor of lifting the moratorium. Satu Kahkonen (since 2016 the World Bank Country Director for Belarus, Moldova, and Ukraine) drew attention to the need to lift the moratorium on the sale of agricultural land in Ukraine. According to her, the yield level in our country is much lower than in European countries, Ukraine needs to develop agriculture and attract investments (The World Bank has called for lifting the moratorium on land sales in Ukraine by 2018, 2017).

\section{CONCLUSIONS}

As Ukraine is approaching the abolition of the moratorium on the sale of agricultural land, large agrarian companies are rapidly increasing their land assets. According to the legislation there are no restrictions on the transfer of land plots of agricultural land for lease to foreigners and stateless persons.

1. Based on the features of lease of agricultural land in Ukraine, we can distinguish the following positive points for investors: (i) agricultural land in Ukraine provides advantages in the presence of long-term lease that guarantees the stability of tenants' land use and in turn contributes to better planning and investment attractiveness, the possibility of applying multi-use 
crop rotation, preventing degradation processes of soil cover, and increasing soil fertility; (ii) the current law allows setting a fixed amount of rent for the land of private property without taking into account the normative monetary valuation. This allows investors to save time and money required to obtain such normative monetary valuation of the land plot; and, (iii) the rent for agricultural land in Ukraine continues to be much lower compared to other countries.

2. Formation of the land market is a necessary component for further development of market economy in Ukraine. That is why it is necessary to create a strong legal framework for the market to be efficient and as transparent and competitive as possible. First of all, it is necessary to adopt the Law of Ukraine "On the circulation of agricultural land" in which it is advisable to implement such provisions of the legal model of a moderately restricted market as: (i) establishment of minimum sizes of agricultural land plots in order to prevent further crushing of what has happened during the parceling of agricultural lands; (ii) establishing the maximum size of agricultural land plots that can be acquired and entrusting the state authority with the obligation to control the acquisition of rights to agricultural land by natural persons and legal entities; (iii) giving pre-emptive right on the acquisition and ownership of agricultural land by natural persons and legal entities; and, (iv) introduction of compulsory alienation (redemption) of agricultural land not used by their owners. The development of a civilized agricultural land market should help to ensure that land buyers can become business entities. To a large extent, this kind of land turnover should ensure the state regulation of the land market, which proceeds from the fact that the buyer of the land should be the one who has the desire and ability to use it effectively and rationally.

3. Today the moratorium on the sale of agricultural land deprives a considerable number of Ukrainian citizens of the opportunity to exercise their constitutional right and thus hinder the development of the agricultural market. Therefore, in order to ensure the full realization of property rights, it is time to create all the conditions for that. It is necessary to take care not to transfer too much land in one hand to prevent the creation of monopolies and to lay down rules for the purchase of land by foreigners. As an alternative to selling land we offer lease of land with a further possibility of redemption and certain rules for land use. This is necessary to ensure that the land is not demanded by only one type of plant or chemical, but adheres to crop rotation rules, pesticide application rules, etc. 


\section{REFERENCES}

Balyuk, G. (2006). Compliance with the requirements of land legislation as a requirement to ensure national security of Ukraine. Land relations and spatial development in Ukraine: materials Intern. scient. conf. (April 13-14, 2006). Kyiv. 157-160.

Dankevych, A. (2007). World land leasing experience. Economy of agroindustrial complex, 3, pp. 138-144.

European Commission (2017). Sales of farmland: Commission issues guidelines to Member States. Press release. Retrieved from https://ec.europa.eu/commission/presscorner/detail/en/IP_17_3901

European Court of Human Rights (2018). Zelenchuk and Tsytsyura v. Ukraine: Judgement on Applications nn. 846/16 and 1075/16 dated May 22, 2018. Retrieved from http://hudoc.echr.coe.int/eng?i=001-183128

Fedchyshyn, D., Ignatenko I. \& Shvydka, V. (2019). Economic and legal differences in patterns of land use in Ukraine. Amazonia Investiga, 18(8), pp. 103-110.

Kulynych, P. (2011). Legal problems of protection and use of agricultural land in Ukraine. Kyiv: Logos.

Litoshenko, O. (2014). The problem of the moratorium on the sale of agricultural land. Legal regulation of the economy, 14, pp. 284-293.

Martynyuk, M. (2017). Agricultural land market in Ukraine: state and prospects of introduction. Economy of agroindustrial complex, 3, pp. 15-21.

Miroshnychenko, A. (2011). Land law of Ukraine. Kyiv: Alerta.

Miroshnychenko, A. (2012). Land law of foreign countries. Retrieved from http://www.amm.org.ua/ua/study-book/23-land-law-foreign

Nivievskyi, O., Strubenhoff, H. (2017). Where Will the Demand for Land Come From? Evidence from Farm Models. Retrieved from https://www.researchgate.net/publication/315807984_Where_Will_the_Deman d_for_Land_Come_From_Evidence_from_Farm_Models (22-I-2020).

Nizalov, D. (2018). About the cancer of the Ukrainian economy, or How a land moratorium harms every Ukrainian. Retrieved from https://www.epravda.com.ua/rus/publications/2018/05/10/636671/

Patyka, N., (2018). Foreign investment in the Ukraine's agriculture: current state and impact on its development. Investments: practice and experience, 5, pp. 26-31.

State Service of Ukraine for Geodesy, Cartography and Cadastre (StateGeoCadastr). (2017). Lease of agricultural land: there is a double gap between the payment for public and private land. Retrieved from http://land.gov.ua/orendasilskohospodarskykh-zemel-zberihaietsia-dvorazovyi-rozryv-mizh-platoiu-zaderzhavni-ta-pryvatni-zemli/

The World Bank has called for lifting the moratorium on land sales in Ukraine by 2018 (2017, Oct. 3). Gordon.ua. Retrieved from 
http://gordonua.com/ukr/news/money/-u-svitovomu-banku-zaklikali-skasuvatimoratorij-na-prodazh-zemli-v-ukrajini-do-2018-roku-210245.html

Top 10 agricultural holdings of Ukraine (2018, July 12). Agroportal. Retrieved from http://agroportal.ua/publishing/infografika/top10-agrokholdingov-ukrainyaktsenty-2017-v-infografike/

Tupalska, O. (2017). Land at the limit. Scientists of NAAS - about 4 problems of soil quality. Retrieved from https://agropolit.com/spetsproekty/358-zemlya-na-mejivcheni-naan--pro-4-problemi-yakosti-gruntiv

Ukraine. (1996). Constitution of Ukraine. Retrieved from https://zakon.rada.gov.ua/laws/show/254\%D0\%BA/96-\%D0\%B2\%D1\%80

Ukraine. (2001). Land Code of Ukraine. Retrieved from https://zakon.rada.gov.ua/laws/show/2768-14

Ukraine. 2003). Commercial Code of Ukraine. Retrieved from https://zakon.rada.gov.ua/laws/show/436-15

Ukraine. Cabinet of Ministers. (2017). Strategy for improving the management mechanism in the field of use and protection of agricultural land of state ownership. Retrieved from https://zakon.rada.gov.ua/laws/show/413-2017$\% \mathrm{D} 0 \% \mathrm{BF} \# \mathrm{n} 12$

Ukraine. State Service for Geodesy, Cartography and Cadastre (StateGeoCadastr) (2016). StateGeoCadastr initiates the bringing of conditions for the use of state lands to market realities. Retrieved from https://www.kmu.gov.ua/ua/news/248773973

Ukrainian Agribusiness Club. (2016). Agro holdings of Ukraine 2016. Kyiv.

Zugriy, O. (2016, Nov. 16-18). Legal aspects of the moratorium on the sale of agricultural land. Strategic-innovative development of economic system subjects in the conditions of globalization: Collection of abstracts of the First International Scientific Practice. Kremenchuk, pp. 271-273. 